Eawag_05699

\title{
Zinc isotope composition of settling particles as a proxy for biogeochemical processes in lakes: Insights from the eutrophic Lake Greifen, Switzerland
}

\author{
Kate Peel, ${ }^{a}$ Dominik Weiss, a,b, ${ }^{\text {and Laura Siggc }}$ \\ a Department of Earth Science and Engineering, Imperial College London, South Kensington, London, UK \\ b Department of Mineralogy, Natural History Museum, Cromwell Road, London, UK \\ c Eawag, Swiss Federal Institute for Aquatic Science and Technology, Dübendorf, Switzerland
}

\begin{abstract}
The isotope composition of zinc ( $\mathrm{Zn}$ ) was determined in settling particles collected monthly over a year in the hypolimnion of the eutrophic Lake Greifen (Switzerland) in order to explore the potential of this novel isotope system as a proxy for biogeochemical processes in aqueous environments. Significant variation in $\delta^{66} \mathrm{Zn}_{\mathrm{JMC}} \mathrm{C}_{-0749 \mathrm{~L}}$ of $0.9 \%$ (where $\left.\delta^{66} \mathrm{Zn}_{\text {JMC3-0749L }}=\left[\left\{{ }^{66} \mathrm{Zn}:{ }^{64} \mathrm{Zn}\right\}_{\text {sample }} /\left\{{ }^{66} \mathrm{Zn}:{ }^{64} \mathrm{Zn}\right\}_{\text {JMC3-0749L }} 1\right] \times 1000\right)$ was found throughout the seasonal cycle of productivity. The most negative $\delta^{66} \mathrm{Zn}_{\mathrm{JMC} 3-0749 \mathrm{~L}}$ values (down to $0.66 \% \pm 0.08 \%$ ) were observed during the productive summer period from June to September, when the $\mathrm{Zn}$ in the settling particles was predominantly associated with organic material, and when $\mathrm{Zn}$ concentrations in the epilimnion were lowest. This observation is likely explained with preferential uptake of the light $\mathrm{Zn}$ isotopes during algal growth. During the other months, the $\mathrm{Zn}$ in the sediment traps showed higher $\delta^{66} \mathrm{Zn}$ values, reflecting increasing contributions of anthropogenic or lithogenic components. The average isotopic signature of the settling particles during the autumn winter spring period $\left(\sim 0.2 \%\right.$ for $\left.\delta^{66} \mathrm{Zn}_{\mathrm{JMC}-0749 \mathrm{~L}}\right)$ was somewhat lower than typical for anthropogenic and natural sources, and this possibly reflects the effect of the preferential adsorption of lighter dissolved $\mathrm{Zn}$ isotopes onto the settling particles. We suggest that Rayleigh fractionation plays a minor role in controlling the isotopic composition of the settling particles in the lake. Our work demonstrates the presence of an obvious seasonal cycle in $\delta^{66} \mathrm{Zn}$, and this suggests that $\mathrm{Zn}$ isotopes can be employed to study nutrient utilization and other biogeochemical processes in lakes and other aquatic environments.
\end{abstract}

Zinc $(\mathrm{Zn})$ is an essential cofactor of many proteins and enzymes, for example, in carbonic anhydrase, which mediates the conversion of $\mathrm{CO}_{2}$ to $\mathrm{HCO}_{3}$ in the photosynthetic process (Frausto Da Silva and Williams 2000). Consequently, $\mathrm{Zn}$ is an essential micronutrient for planktonic algae, and it plays an important part in the biogeochemical cycle of various elements in aquatic systems. In oceans and lakes alike, $\mathrm{Zn}$ shows a nutrientlike vertical concentration profile similar to silica and nitrogen: it is depleted in the surface waters resulting from uptake by algae (Bruland 1980; Reynolds and HamiltonTaylor 1992). It has been proposed that the $\mathrm{Zn}$ stable isotope system may develop into a tracer for nutrient availability in both modern and ancient waters (Albarède 2004; Anbar and Rouxel 2007). Preliminary analyses of Zn isotopes in seawater and algae agree with the assumption that biological activity in the surface waters preferentially consumes the light isotope, leaving the remaining dissolved $\mathrm{Zn}$ pool isotopically heavy (Bermin et al. 2006; John et al. 2007a). The link between $\mathrm{Zn}$ isotopes and productivity was first explored by Maréchal and coworkers (Maréchal et al. 2000) for the oceans. They inferred that depletion of light $\mathrm{Zn}$ isotopes in ferromanganese nodules was due to biological activity in the upper water column, though this interpretation is challenged by the fact that $\mathrm{Zn}$ is regenerated in the deep ocean. Nevertheless, sediment trap samples from the same study revealed a seasonal isotopic fluctuation consistent with biological pumping during the high-productivity period in a coastal upwelling region. A

\footnotetext{
* Corresponding author: d.weiss@imperial.ac.uk
}

subsequently established $\mathrm{Zn}$ isotope record in the carbonate fraction of sediment cores from the equatorial Pacific showed significant variations, which were interpreted as a function of strength of upwelling, nutrient availability, and hence productivity (Pichat et al. 2003). Preliminary results for settling particles from a Swiss lake showed variation of $\mathrm{Zn}$ isotopes over a few months related to the spring algal bloom and subsequent depletion of $\mathrm{Zn}$ in surface waters (Cloquet et al. 2007).

Unlike most other transition metals, $\mathrm{Zn}$ has only one common oxidation state, so whereas for elements such as iron $(\mathrm{Fe})$ and copper $(\mathrm{Cu})$, redox reactions can be a source of large fractionation, uptake by plankton may be among the most prominent processes affecting $\mathrm{Zn}$ isotopes in the environment. The range of reported $\delta^{66} \mathrm{Zn}_{\mathrm{JMC} 3-0749 \mathrm{~L}}$ (where $\delta^{66} \mathrm{Zn}$ is expressed relative to the Johnson Matthew Company batch 3-0749L standard) for biological materials extends from $0.9 \%$ to $+0.8 \%$; this range contrasts with igneous rocks (basalts, granites, granodiorites, and andesites) or "common" anthropogenic sources, which tend to fall within the range of $+0.1 \%$ o to $+0.6 \%$ (Wilkinson et al. 2005; John et al. 2007b; Sonke et al. 2008; Sivry et al. 2008).

The $\mathrm{Zn}$ isotope signatures observed in settling particles may be affected, however, by other biogeochemical processes, such as adsorption of dissolved $\mathrm{Zn}$ onto cell walls and mineral surfaces. Systematic enrichment of heavy $\mathrm{Zn}$ isotopes ranging between $+0.19 \%$ and $+0.43 \%$ has been shown in cultured diatoms cells depending on species and experimental conditions such as $\mathrm{pH}$, ion strength, and speciation (Gélabert et al. 2006). John and coworkers (John et al. 2007a) determined fractionation factors between 


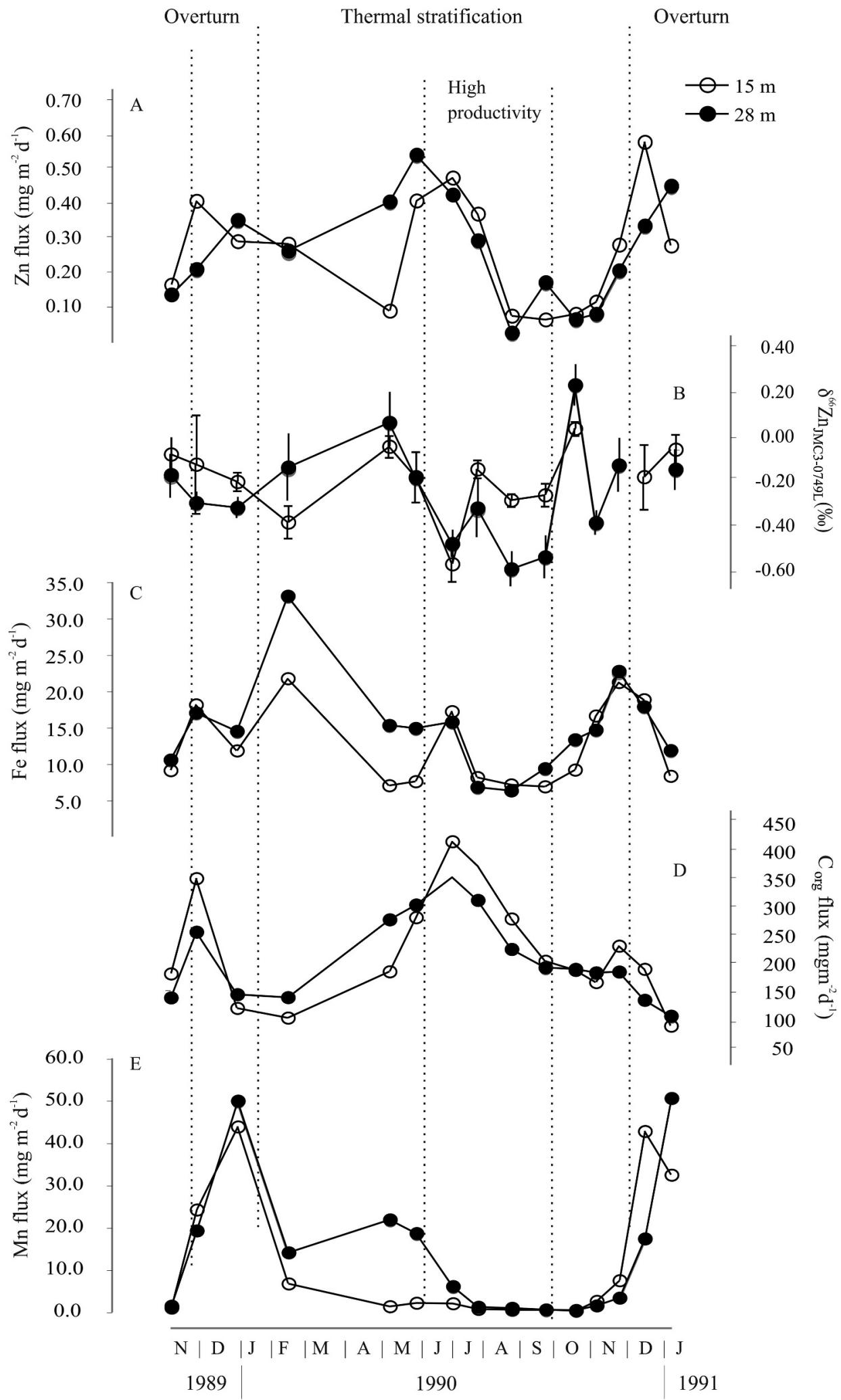

Fig. 1. (A) Sedimentation rate of $\mathrm{Zn}$ expressed in $\mathrm{mg} \mathrm{m}^{2} \mathrm{~d}{ }^{1}$; (B) $\mathrm{Zn}$ isotope composition expressed in $\delta^{66} \mathrm{Zn}$ relative to the JMC3 0749L Zn standard (error bars are $\pm 2 \sigma$ for a minimum of three replicate analyses); and ( $\mathrm{C} \mathrm{E}$ ) sedimentation rates of $\mathrm{Fe}, \mathrm{C}_{\mathrm{org}}$, and $\mathrm{Mn}$ in settling particles collected in traps at $15 \mathrm{~m}$ and $28 \mathrm{~m}$ depth between November 1989 and January 1991 expressed in $\mathrm{mg} \mathrm{m}^{2} \mathrm{~d}^{1}$. Samples are missing during March April 1990 because one set of sediment traps could not be retrieved. 
water and algae cell ranging from $\quad 0.05 \%$ to $+0.38 \%$ for unwashed cells and up to $0.8 \%$ for washed cells (depending on the $[\mathrm{Zn}]$ in solution). Similarly, in stream waters affected by historical mining, Borrok and coworkers (Borrok et al. 2008) observed an apparent isotopic separation process between dissolved and solid $\mathrm{Zn}$ of $\sim 0.3 \%$ for ${ }^{66} \mathrm{Zn}:{ }^{64} \mathrm{Zn}$.

The aim of the present work was to explore the potential of the $\mathrm{Zn}$ isotope system to characterize biogeochemical processes in the aqueous environment. This was achieved by analyzing settling particles collected in the hypolimnion of Lake Greifen in Switzerland over a year with respect to the seasonal cycle of productivity and nutrient availability.

\section{Site description and previous work}

Lake Greifen is a eutrophic lake located in a densely populated area, $12 \mathrm{~km}$ east of Zürich, Switzerland. The surface area is $8.5 \times 10^{6} \mathrm{~m}^{2}$, its volume is $150 \times 10^{6} \mathrm{~m}^{3}$, and the maximum depth is $32 \mathrm{~m}$. The alkalinity is $\sim 3.6$ $4.1 \mathrm{mmol} \mathrm{L} 1$, and the $\mathrm{pH}$ ranges between 7.5 and 8.5, with variations in time and depth. Dissolved organic carbon is $34 \mathrm{mg} \mathrm{L}^{1}$ in the water column (Xue et al. 1995). The estimated residence time of the water is $1.1 \mathrm{yr}$ (Sigg et al. 1996), and the estimated residence time of $\mathrm{Zn}$ is $120 \pm 30 \mathrm{~d}$ (Santschi 1984). The tributaries of the lake are loaded with nutrients and pollutants from sewage and agriculture. The predominant part of $\mathrm{Zn}(87 \%)$ is incorporated in the lake sediments after uptake by algae, and only $13 \%$ is eliminated by the lake outflow. Internal recycling of $\mathrm{Zn}$ from sediments plays a minor role (Sigg et al. 1996). Seasonal cycles of productivity and thermal stratification lead to variable physiochemical conditions, which control the cycling of trace elements in the lake system. Thermal stratification lasts approximately from May to December, and lake overturn usually takes place in December to January. During summer stagnation, from approximately June to December, the hypolimnion becomes anoxic below 10-m depth. These changes in redox state mean that there is an active manganese $(\mathrm{Mn})$ cycle taking place. Manganese oxides form a large part of the settling particles during overturn, and a peak in their sedimentation rate coincides with that of $\mathrm{Zn}$, indicating that adsorption to $\mathrm{Mn}$ oxides is a mechanism of $\mathrm{Zn}$ sedimentation (Sigg et al. 1995). The composition of settling particles caught in sediment traps reflects the seasonal variations in productivity and redox cycles. The sedimentation rate of organic carbon $\left(\mathrm{C}_{\mathrm{org}}\right)$ increases in the summer months (June to August) due to the increase in productivity. The maximum sedimentation rate of $\mathrm{Zn}$ during summer occurs at the same time. The $[\mathrm{Zn}]$ profile in the water column throughout the seasonal cycle is similar to major nutrients such as P and Si. Zinc is depleted from the epilimnion during summer stagnation to between $30 \%$ and $50 \%$ of its concentration during mixing, but is never completely depleted (Sigg et al. 1995). During lake overturn, $[\mathrm{Zn}]$ is homogeneous throughout the water column. Investigations of the $\mathrm{Zn}$ speciation (Xue and Sigg 1994; Xue et al. 1995) indicate that between 5\% and $10 \%$ of total dissolved $\mathrm{Zn}$ is present as aqua $\mathrm{Zn}^{2+}$ ions and $30 \%$ to
$40 \%$ is present as weak complexes and is easily available for interaction with the biota. The spatial and temporal evolution of the [Zn] depth profile at the Lake Greifen is shown and discussed in all detail elsewhere (Sigg et al. 1995, 1996).

\section{Methods}

Sample description and elemental analysis The settling particles were collected and their elemental concentrations determined during a previous study (Sigg et al. 1995, 1996). We only give a short summary here. Sediment traps were employed in the deepest part of the lake at depths of $15 \mathrm{~m}$ and $28 \mathrm{~m}$ and retrieved every 3 weeks for 15 months from October 1989 to January 1991. Samples are missing during March April 1990 because one set of sediment traps could not be retrieved. The sedimentation rates were quantified by weighing the dry material. Samples were freeze-dried and stored as dry powders in the dark at $4^{\circ} \mathrm{C}$ at Eawag (Switzerland) until further analysis. The settling particles were digested with $\mathrm{HCl}-\mathrm{HNO}_{3}$ using microwave digestion. Iron, $\mathrm{Mn}, \mathrm{Zn}$, and $\mathrm{Ca}$ were determined by inductively coupled plasma optical emission spectrometry (ICP-OES), $\mathrm{P}$ was determined by the molybdate spectrophotometric method, and organic $\mathrm{C}$ and $\mathrm{N}$ were determined by $\mathrm{CHN}$ analyzer.

Zinc isotope analysis For the isotope analysis, samples were shipped to Imperial College London (IMP, U.K.) in February 2007. Approximately $0.1 \mathrm{~g}$ of each settling particle sample was digested in 5:2:1 mL of Aristar-grade (VWR) concentrated $\mathrm{HF}-\mathrm{HNO}_{3}-\mathrm{HClO}_{4}$ acid mixture in open Teflon vessels in a heating block at $90^{\circ} \mathrm{C}$ for $3 \mathrm{~h}$, $140^{\circ} \mathrm{C}$ for $3 \mathrm{~h}$, and $190^{\circ} \mathrm{C}$ for $10 \mathrm{~h}$ (Thompson and Walsh 1989). Evaporated fractions were taken up in $6 \mathrm{~mL}$ of $7 \mathrm{~mol} \mathrm{~L}{ }^{1} \mathrm{HCl}$ and heated for $24 \mathrm{~h}$ at $80^{\circ} \mathrm{C}$ before being evaporated. Finally, the samples were taken up in $2 \mathrm{~mL}$ of ultrapure grade (Romil) 7 mol L ${ }^{1} \mathrm{HCl}$.

Ion-exchange chromatography was used to separate $\mathrm{Zn}$ fractions from matrix components prior to isotope analysis (Chapman et al. 2006). Recoveries were monitored and yielded $>95 \%$. All isotopic measurements were made using the IsoProbe multicollector ICP mass spectrometer (Thermo Scientific) connected to an Aridus desolvating nebulizer (Cetac Technologies). Instrumental background and acid matrix blank corrections were performed using on-peak blank measurements taken before every sample and standard. Sample and standard measurements were made by taking 25 five-second integrations. All samples were spiked with a $\mathrm{Cu}$ standard to act as an internal mass discrimination monitor. Standards were made up using inhouse $\mathrm{Cu}$ and $\mathrm{Zn}$ solutions (IMP $\mathrm{Zn}$ and IMP $\mathrm{Cu}$ ). Sample and standard solutions for each analytical run were concentration matched to within $\pm 10 \%$. Mass discrimination effects were corrected using a combined samplestandard bracketing and interelement correction procedure. Nickel (Ni) interferences on ${ }^{64} \mathrm{Zn}$ were carefully monitored. Full descriptions of the analytical protocol and the inhouse solutions are given elsewhere (Mason et al. 2004; Peel et al. 2007; Weiss et al. 2007).

The value of $\delta^{66} \mathrm{Zn}$ was calculated using $\delta^{66} \mathrm{Zn}=$ $\left(\left[\mathrm{R}_{\text {sample }}\right]:\left[\mathrm{R}_{\text {standard }}\right] \quad 1\right) \times 1000(\%)$, where $\mathrm{R}_{\text {sample }}$ is 
Table 1. Zn isotope composition expressed as $\delta^{66} \mathrm{Zn}$ relative to the JMC3 0749L standard, $\pm 2 \sigma$ determined from a minimum of three replicate analyses, total sedimentation rates for settling particles, and sedimentation rates of $\mathrm{Zn}, \mathrm{C}$ org $, \mathrm{P}, \mathrm{N}, \mathrm{Ca}, \mathrm{Fe}$, and $\mathrm{Mn}$ (taken from Sigg et al. 1995) at $15 \mathrm{~m}$ and $28 \mathrm{~m}$ depth.

\begin{tabular}{|c|c|c|c|c|c|c|}
\hline \multirow{2}{*}{$\begin{array}{l}\text { Sampling } \\
\text { depth }\end{array}$} & \multicolumn{2}{|c|}{ Sampling period } & \multirow{2}{*}{$\underset{(\%)}{\delta^{66} \mathrm{Zn}_{\text {JMC3-0749L }}}$} & \multirow[b]{2}{*}{ $\pm 2 \sigma$} & \multirow{2}{*}{$\begin{array}{c}\text { Total } \\
\left(\mathrm{g} \mathrm{m}^{2} \mathrm{~d}^{1}\right)\end{array}$} & \multirow{2}{*}{$\begin{array}{c}\mathrm{Zn} \\
\left(\mathrm{mg} \mathrm{m}^{2} \mathrm{~d}^{1}\right)\end{array}$} \\
\hline & Start & End & & & & \\
\hline \multirow[t]{15}{*}{$15 \mathrm{~m}$} & 18 Oct 89 & 22 Nov 89 & 0.11 & 0.08 & 1.64 & 0.25 \\
\hline & 22 Nov 89 & 13 Dec 89 & 0.16 & 0.23 & 2.17 & 0.48 \\
\hline & 13 Dec 89 & 16 Jan 90 & 0.24 & 0.04 & 1.18 & 0.37 \\
\hline & 16 Jan 90 & 27 Feb 90 & 0.44 & 0.08 & 1.56 & 0.36 \\
\hline & 27 Apr 90 & 22 May 90 & 0.08 & 0.05 & 1.58 & 0.17 \\
\hline & 22 May 90 & 13 Jun 90 & 0.22 & 0.12 & 6.83 & 0.48 \\
\hline & 13 Jun 90 & 13 Jul 90 & 0.63 & 0.08 & 7.73 & 0.54 \\
\hline & 13 Jul 90 & 03 Aug 90 & 0.18 & 0.04 & 7.34 & 0.44 \\
\hline & 03 Aug 90 & 31 Aug 90 & 0.33 & 0.03 & 3.22 & 0.16 \\
\hline & 31 Aug 90 & 28 Sep 90 & 0.31 & 0.05 & 2.48 & 0.15 \\
\hline & 28 Sep 90 & 23 Oct 90 & 0.01 & 0.03 & 1.50 & 0.16 \\
\hline & 23 Oct 90 & 09 Nov 90 & & & 1.99 & 0.20 \\
\hline & 09 Nov 90 & 28 Nov 90 & & & 2.38 & 0.36 \\
\hline & 28 Nov 90 & 19 Dec 90 & 0.22 & 0.15 & 1.88 & 0.64 \\
\hline & 19 Dec 90 & $10 \operatorname{Jan} 91$ & 0.09 & 0.07 & 1.07 & 0.35 \\
\hline \multirow{15}{*}{$28 \mathrm{~m}$} & 18 Oct 89 & 22 Nov 89 & 0.21 & 0.11 & 1.46 & 0.22 \\
\hline & 22 Nov 89 & 13 Dec 89 & 0.34 & 0.05 & 1.70 & 0.29 \\
\hline & 13 Dec 89 & 16 Jan 90 & 0.37 & 0.05 & 1.37 & 0.42 \\
\hline & 16 Jan 90 & 27 Feb 90 & 0.18 & 0.16 & 2.12 & 0.34 \\
\hline & 27 Apr 90 & 22 May 90 & 0.04 & 0.14 & 2.50 & 0.48 \\
\hline & 22 May 90 & 13 Jun 90 & 0.23 & 0.06 & 6.69 & 0.60 \\
\hline & 13 Jun 90 & 13 Jul 90 & 0.54 & 0.06 & 7.07 & 0.49 \\
\hline & 13 Jul 90 & 03 Aug 90 & 0.37 & 0.14 & 6.12 & 0.37 \\
\hline & 03 Aug 90 & 31 Aug 90 & 0.66 & 0.08 & 2.84 & 0.11 \\
\hline & 31 Aug 90 & 28 Sep 90 & 0.60 & 0.10 & 2.11 & 0.25 \\
\hline & 28 Sep 90 & 23 Oct 90 & 0.21 & 0.10 & 1.50 & 0.15 \\
\hline & 23 Oct 90 & 09 Nov 90 & 0.44 & 0.06 & 1.65 & 0.17 \\
\hline & 09 Nov 90 & 28 Nov 90 & 0.17 & 0.13 & 2.04 & 0.29 \\
\hline & 28 Nov 90 & 19 Dec 90 & & & 1.46 & 0.41 \\
\hline & 19 Dec 90 & 10 Jan 91 & 0.19 & 0.10 & 1.33 & 0.52 \\
\hline
\end{tabular}

the $66 \mathrm{Zn}:{ }^{64} \mathrm{Zn}$ ratio of the sample, and $\mathrm{R}_{\text {standard }}$ is the $66 \mathrm{Zn}:{ }^{64} \mathrm{Zn}$ ratio of the bracketing IMP $\mathrm{Zn}$ standard. All $\delta 66 \mathrm{Zn}$ results are reported relative to JMC 3-0749L $\mathrm{Zn}$, which has a $\delta^{66} \mathrm{Zn}$ value relative to the IMP $\mathrm{Zn}$ solution of $0.09 \%$ o $0.05 \%$ o ( $\pm 2 \mathrm{SD}, n=12$ ). Reproducibility was assessed by repeated measurement of the BCR 280 standard (lake sediment) and was $\pm 0.08 \%$ ( $\pm 2 \mathrm{SD}, n=$ $12)$. Errors on the reported $\delta^{66} \mathrm{Zn}$ values are two standard deviations calculated from a minimum of three replicate analyses. Precision for a single-element $\mathrm{Zn}$ solution (Romil) over a period of $3 \mathrm{yr}$ was better than $\pm 0.04 \%$. Internal precision for each measurement was better than $0.002 \%$ (2 SE at 95\% confidence level) for all ratios. Procedural blank contributions were typically $20 \mathrm{ng}$ of $\mathrm{Zn}$, which was $<3 \%$ and insignificant. Accuracy was checked using repeated analyses of the international geological standard BCR 1 , and the $\delta^{66} \mathrm{Zn}_{\text {JMC3-0749L }}$ values agreed within error $(0.33 \pm 0.07)$ with previously published values (Cloquet et al. 2007).

\section{Results}

The $\mathrm{Zn}$ isotope ratios (expressed using $\delta^{66} \mathrm{Zn}_{\text {JMC3-0749L }}$ in $\%$ ) of the settling particles and the sedimentation rates of
$\mathrm{Zn}, \mathrm{C}_{\mathrm{org}}, \mathrm{Mn}$, and $\mathrm{Fe}$ (expressed using fluxes in $\left.\mathrm{mg} \mathrm{m} 2 \mathrm{~d}{ }^{1}\right)$ at both depths over the year are shown in Fig. 1 and Table 1 . The value of $\delta^{66} \mathrm{Zn}_{\mathrm{JMC} 3-0749 \mathrm{~L}}$ varies by $0.9 \%$, ranging from $0.66 \%$ to $+0.21 \%$. This falls largely within the previously determined isotopic range of $\mathrm{Zn}$ in terrestrial geological material of $0.4 \%$ o to $+1.4 \%$ (Cloquet et al. 2006). Samples collected during the summer are below this range ( $\delta^{66} \mathrm{Zn}_{\mathrm{JMC} 3-0749 \mathrm{~L}}$ between $0.44 \%$ and $0.66 \%$ ) yet above the lowest measured $\delta^{66} \mathrm{Zn}_{\mathrm{JMC} 3-0749 \mathrm{~L}}$ value of

$0.91 \%$ reported for palm leaves (Viers et al. 2007). The $\delta$ values and seasonal pattern for both the $15-\mathrm{m}$ and $28-\mathrm{m}$ sediment traps are similar, as may be expected from their similar chemical and mineralogical composition. The $\delta^{66} \mathrm{Zn}$ fluctuates throughout the year, but peaks of isotopically heavy $\mathrm{Zn}$ are seen in May and October, and the isotopically lightest values occur between June and September. During the autumn, winter, and early to midspring months (November to April), when biological activity is small (in general lower $\mathrm{C}_{\text {org }}$ fluxes), the average value of $\delta^{66} \mathrm{Zn}_{\text {JMC3-0749L }}$ is $\sim 0.2 \%$ at both depths; this is significantly higher than during the summer months (June to September), which average $\delta^{66} \mathrm{Zn}_{\mathrm{JMC} 3-0749 \mathrm{~L}}$ values of

$0.36 \%$ and $0.54 \%$ at $15 \mathrm{~m}$ and $28 \mathrm{~m}$, respectively, and the late summer (October), which showed $\delta^{66} \mathrm{Zn}_{\mathrm{JMC} 3-0749 \mathrm{~L}}$ 
Table 1. Extended.

\begin{tabular}{|c|c|c|c|c|c|}
\hline $\begin{array}{c}\mathrm{C}_{\mathrm{org}} \\
\left(\mathrm{mg} \mathrm{m}^{2} \mathrm{~d}^{1}\right)\end{array}$ & $\begin{array}{c}\mathrm{P} \\
\left(\mathrm{mg} \mathrm{m}^{2} \mathrm{~d}^{1}\right)\end{array}$ & $\begin{array}{c}\mathrm{N}^{2} \\
\left.\mathrm{mg} \mathrm{m}^{2} \mathrm{~d}^{1}\right)\end{array}$ & $\begin{array}{c}\mathrm{Ca} \\
\left(\mathrm{mg} \mathrm{m}^{2} \mathrm{~d}^{1}\right)\end{array}$ & $\begin{array}{c}\mathrm{Fe} \\
\left(\mathrm{mg} \mathrm{m}^{2} \mathrm{~d}^{1}\right)\end{array}$ & $\begin{array}{c}\mathrm{Mn} \\
\left(\mathrm{mg} \mathrm{m}^{2} \mathrm{~d}^{1}\right)\end{array}$ \\
\hline 180 & 6.6 & 25.5 & 288 & 9.2 & 1.2 \\
\hline 348 & 13.8 & 58.7 & 237 & 18.2 & 24.3 \\
\hline 118 & 4.9 & 17.0 & 181 & 11.9 & 43.9 \\
\hline 101 & 3.6 & 13.1 & 266 & 21.8 & 6.9 \\
\hline 183 & 5.2 & 32.5 & 190 & 7.1 & 1.5 \\
\hline 279 & 8.0 & 38.3 & 2253 & 7.6 & 2.3 \\
\hline 413 & 11.7 & 52.0 & 2395 & 17.3 & 2.1 \\
\hline 370 & 9.1 & 55.5 & 2362 & 8.2 & 0.8 \\
\hline 277 & 7.3 & 39.2 & 903 & 7.2 & 0.7 \\
\hline 202 & 5.1 & 28.5 & 641 & 6.9 & 0.7 \\
\hline 186 & 3.7 & 24.0 & 265 & 9.2 & 0.4 \\
\hline 164 & 4.9 & 25.9 & 369 & 16.7 & 2.7 \\
\hline 229 & 7.0 & 37.7 & 418 & 21.3 & 7.6 \\
\hline 188 & 6.4 & 32.1 & 305 & 18.9 & 42.9 \\
\hline 87 & 3.8 & 13.8 & 180 & 8.4 & 32.5 \\
\hline 137 & 4.7 & 21.1 & 294 & 10.6 & 1.6 \\
\hline 253 & 10.1 & 43.3 & 204 & 17.1 & 19.3 \\
\hline 143 & 5.6 & 20.0 & 210 & 14.5 & 50.0 \\
\hline 137 & 5.1 & 17.2 & 361 & 33.2 & 14.2 \\
\hline 275 & 11.2 & 63.4 & 225 & 15.4 & 22.0 \\
\hline 301 & 10.8 & 39.4 & 2158 & 14.9 & 18.7 \\
\hline 351 & 10.9 & 47.5 & 2239 & 15.8 & 6.2 \\
\hline 309 & 7.8 & 48.0 & 1975 & 6.8 & 1.3 \\
\hline 223 & 7.3 & 33.4 & 812 & 6.3 & 1.1 \\
\hline 191 & 4.2 & 27.5 & 578 & 9.4 & 0.7 \\
\hline 188 & 3.9 & 25.4 & 260 & 13.4 & 0.6 \\
\hline 181 & 5.3 & 25.9 & 291 & 14.7 & 1.6 \\
\hline 183 & 5.5 & 26.9 & 388 & 22.8 & 3.5 \\
\hline 133 & 6.0 & 20.5 & 252 & 17.9 & 17.5 \\
\hline 105 & 4.7 & 17.3 & 223 & 11.9 & 50.6 \\
\hline
\end{tabular}

values of $+0.21 \%$ and $+0.01 \%$ at $28 \mathrm{~m}$ and $15 \mathrm{~m}$, respectively. Low $\delta^{66} \mathrm{Zn}$ values coincide in general with increased $\mathrm{C}_{\text {org }}, \mathrm{P}$, and total sedimentation rates in the summer months, and high $\delta$ values in May and October show a possible link to a decrease in these rates (Table 1).

\section{Discussion}

Autumn winter spring period The average isotope signature during the autumn-winter-spring period is around

$0.2 \%$ for $\delta^{66} \mathrm{Zn}_{\text {JMC3-0749L }}$ at both sampling depths. This is lower than expected if the $\mathrm{Zn}$ were derived from natural soil dust only, which ranges approximately between +0.2 to +0.6 (Albarède 2004; Wilkinson et al. 2005; Cloquet et al. 2006). However, the lake is situated in an area of urban and agricultural land, and the dominant sources of $\mathrm{Zn}$ via rivers and via atmospheric deposition are of anthropogenic origin (Sigg et al. 1995, 1996). Previous work has established that over the period of a year, the input of $\mathrm{Zn}$ to the lake consists of $\sim 74 \%$ from tributaries and $\sim 26 \%$ from atmospheric deposition. The main sources of $\mathrm{Zn}$ in the tributaries are from house installations and $\mathrm{Zn}$ contained in manure, while atmospheric deposition is mainly derived from waste incineration (Sigg et al. 1995, 1996).
Sonke et al. (2008) suggested that the global pool of anthropogenic $\mathrm{Zn}$ emissions, including waste combustion, mining dust, automotive fuel, and brake emissions, clusters around $\delta^{66} \mathrm{Zn}_{\mathrm{JMC} 3-0749 \mathrm{~L}}$ values of $+0.1 \%$ to $+0.2 \%$. As such, anthropogenic $\mathrm{Zn}$ is likely less enriched in the heavy isotope than natural sources. More depleted $\mathrm{Zn}$ isotope signatures were determined in rainfall in Montpellier, France, ranging between $0.1 \%$ and $0.2 \%$ o (Cloquet et al. 2007), and in aerosols collected in Sao Paulo, Brazil and around a smelter in Belgium, ranging between $1.0 \%$ and $+0.5 \%$ (Gioia et al. 2008). Zinc isotope studies of polluted rivers have been conducted in the Seine, France (Chen et al. 2008), and in catchments in the Iberian Pyrite Belt (Spain), in Montana (U.S.), and in Colorado (U.S.) (Borrok et al. 2008). The study in the Seine River Basin reported $\delta^{66} \mathrm{Zn}_{\text {JMC3-0749L }}$ values of $0.02 \%$ to $0.07 \%$ o for roof runoff in the Paris area, with a slightly lower $\delta 66 \mathrm{Zn}$ value of

$0.10 \%$ for leached roof cover (Chen et al. 2008). A higher value of $+0.28 \%$ was found for untreated sewage and water entering a wastewater treatment plant, although the total output of $\mathrm{Zn}$ from the plant (dissolved and suspended) was lower, showing a $\delta^{66} \mathrm{Zn}_{\mathrm{JMC} 3-0749 \mathrm{~L}}$ value of $+0.07 \%$. In agricultural areas, $\mathrm{Zn}$ entering the Seine River was isotopically heavier, showing values such as $+0.19 \%$ to 
$+0.42 \%$ for $\mathrm{N}, \mathrm{P}$, and $\mathrm{K}$ fertilizers, and $+0.31 \%$ for treatment sludge reused as compost typifying the inputs (Chen et al. 2008). The average $\delta^{66} \mathrm{Zn}_{\text {JMC3-0749L }}$ value for stream waters draining abandoned historical mining districts in Spain and the U.S. varied from $+0.02 \%$ to $+0.46 \%$ (Borrok et al. 2008). In conclusion, the $\mathrm{Zn}$ (dissolved and solid) delivered to Lake Greifen via the atmosphere and the tributaries is likely to be heavier than the measured value of $0.2 \%$ in the settling particles. (Atmospheric deposition and river waters were not collected during the sampling period.) However, Borrok et al. (2008) determined an apparent separation factor of $0.3 \%$ for ${ }^{66} \mathrm{Zn}$ between the dissolved and the solid $\mathrm{Zn}$ reservoir, with the particles taking up the lighter $\mathrm{Zn}$ isotope. Such an isotopic offset applied to the measured value of $0.2 \%$ in the settling particles leaves the dissolved $\mathrm{Zn}$ with a $\delta^{66} \mathrm{Zn}$ value of around $+0.1 \%$. This calculated $\delta^{66} \mathrm{Zn}$ value then falls within the previously postulated "common anthropogenic Zn" value by Sonke et al. (2008) and John et al. (2007b).

A potential process that can explain the offset between dissolved $\mathrm{Zn}$ and sinking particles is the adsorption of isotopically light $\mathrm{Zn}$ on mineral particles (Pokrovsky et al. 2005; Balistrieri et al. 2008; Juillot et al., 2008). Batch experiments with $\mathrm{Zn}$ and various oxides showed that the separation factor between solution and solid (where $\Delta^{66} \mathrm{Zn}_{\text {solution-solid }}=\delta^{66} \mathrm{Zn}_{\text {solution }} \quad \delta^{66} \mathrm{Zn}_{\text {solid }}$ ) ranges between $0.6 \%$ and $+0.2 \%$, depending on speciation and solution $\mathrm{pH}$. For birnessite $\left(\delta-\mathrm{MnO}_{x} \cdot n \mathrm{H}_{2} \mathrm{O}\right)$, a $\Delta^{66} \mathrm{Zn}_{\text {solution-solid }}$ value of $0.17 \%$ o $\pm 0.06 \%$ was determined. This fractionation could partly account for the observed lighter $\mathrm{Zn}$ in the settling particles in this study. The $\mathrm{Mn}$ phases in Lake Greifen have not been determined, but in other Swiss lakes with comparable water chemistry, the principle Mn-oxide in sediments is vernadite, a structure similar to $\gamma-\mathrm{MnO}_{2}$ and somewhat different from birnessite (Wehrli et al. 1995). Another factor that contributes to the lighter than expected $\mathrm{Zn}$ isotope signature in the settling particles during the autumn winter fall period is a possibly significant contribution from algae (see, e.g., the significant $\mathrm{C}_{\text {org }}$ flux during the early autumn).

Summer high-productivity period The settling particles display the most negative $\delta^{66} \mathrm{Zn}_{\mathrm{JMC} 3-0749 \mathrm{~L}}$ values (up to

$0.66 \%$ ) during the summer high-productivity period (June to September). During this period, organic matter and calcite with very little $\mathrm{Mn}$ dominate the composition of the particles, and these samples are representative of algal material (Table 1; Sigg et al., 1996). Organic carbon $\left(\mathrm{C}_{\text {org }}\right)$ is well correlated with $\mathrm{P}$ and $\mathrm{N}$, indicating that biological material is the common source. The molar $\mathrm{Zn}: \mathrm{P}$ ratios in summer samples appear close to that expected of algae (0.01 0.03), implying that a significant fraction of the sedimenting $\mathrm{Zn}$ is associated with organic material, either incorporated in the cells or bound to the surface. Zink in Lake Greifen is not released from the particles back to the water column by bacterial respiration, as evidenced by the high percentage of $\mathrm{Zn}$ removed from the lake system by sedimentation, and the lack of increase in $[\mathrm{Zn}]$ with depth in the hypolimnion (Sigg et al. 1996). This means that the isotopic composition of the particles is unlikely to have changed significantly from that of the algae in the surface layers.

Recent experimental work on isotopic fractionation during $\mathrm{Zn}$ uptake by marine diatom cells under nonlimiting conditions (as is typical for Lake Greifen even during the summer high productivity) reported $\Delta^{66} \mathrm{Zn}_{\text {cell-media }}$ (where $\left.\Delta^{66} \mathrm{Zn}_{\text {cell-media }}=\delta^{66} \mathrm{Zn}_{\text {cell }} \quad \delta^{66} \mathrm{Zn}_{\text {media }}\right)$ of $0.8 \%$ ( John et al. 2007a). This fractionation factor is representative for a low-affinity $\mathrm{Zn}$ transport pathway. The low $\delta^{66} \mathrm{Zn}_{\text {JMC3-0749L }}$ values of the settling particles in the summer are in line with algae taking up the light isotope preferentially. This suggests that externally adsorbed $\mathrm{Zn}$ is not making a major contribution to the $\delta^{66} \mathrm{Zn}$ during the summer. Low contribution of adsorption on the freshwater algae is confirmed by culture experiments carried out under conditions relevant for Lake Greifen, in which total $\mathrm{Zn}$ concentration measured for algae was almost identical to intracellular Zn (Knauer et al. 1997).

Operation of a non-Rayleigh type fractionation mechanism? The $\delta^{66} \mathrm{Zn}$ of settling particles increases markedly during the October collection period, up to the highest $\delta^{66} \mathrm{Zn}_{\text {JMC3-0749L }}$ value of the year at $28-\mathrm{m}$ depth $(0.21 \%$ o $0.1 \%$ ). The $\mathrm{P}$ and $\mathrm{C}_{\text {org }}$ sedimentation rates are at a low point at that time, indicating that the high-productivity summer period is at an end (Table 1; Fig. 1)

This heavy isotope signature of $\mathrm{Zn}$ could represent a Rayleigh effect where the high productivity of the summer bloom causes a depletion of $\mathrm{Zn}$ in the surface waters, and as the light isotope is removed preferentially, the remaining dissolved $\mathrm{Zn}$ pool becomes isotopically heavy. A similar explanation was suggested for observed $\mathrm{Zn}$ isotope patterns in settling particles at another Swiss lake (Cloquet et al. 2007), where the lowest isotope ratios occurred during the spring algal bloom, followed by a sharp increase when $\mathrm{Zn}$ became depleted in the water. We argue, however, against such a mechanism operating in Lake Greifen for the following reasons.

First, we note that the $\mathrm{Zn}$ concentrations in water, although lower than during the winter period, are still higher in the October samples compared to the summer samples (Fig. 2). Second, a plot of the measured isotope data and the fraction of dissolved $\mathrm{Zn}$ remaining in the lake water along with models for a Rayleigh-type and an equilibrium-type fractionation process (Fig. 3) (using the experimentally determined $\Delta^{66} \mathrm{Zn}_{\text {cell-media }}$ of $\quad 0.8 \%$ and an initial $\delta$ value for dissolved $\mathrm{Zn}$ in the epilimnion of $0.1 \%$ ) does not support the operation of a Rayleigh-type fractionation mechanism. Third, we note that the increase of [ $\mathrm{Zn}]$ during September and October in the lake appears to correspond to an increased water inflow (see fig. 5 in Sigg et al., 1996). This increase may be due to rain events, which may have brought more $\mathrm{Zn}$ into the lake, possibly bound to allochthonous particles. The composition of the particles (Table 1) indicates that the particles in the period between 28 September 1990 and 23 October 1990 contain more Fe than during summer, which could be indicative of allochthonous particles. So an alternative explanation would be that in October, more $\mathrm{Zn}$ is carried to the lake with allochthonous particles, where $\delta^{66} \mathrm{Zn}$ is expected to be higher. 


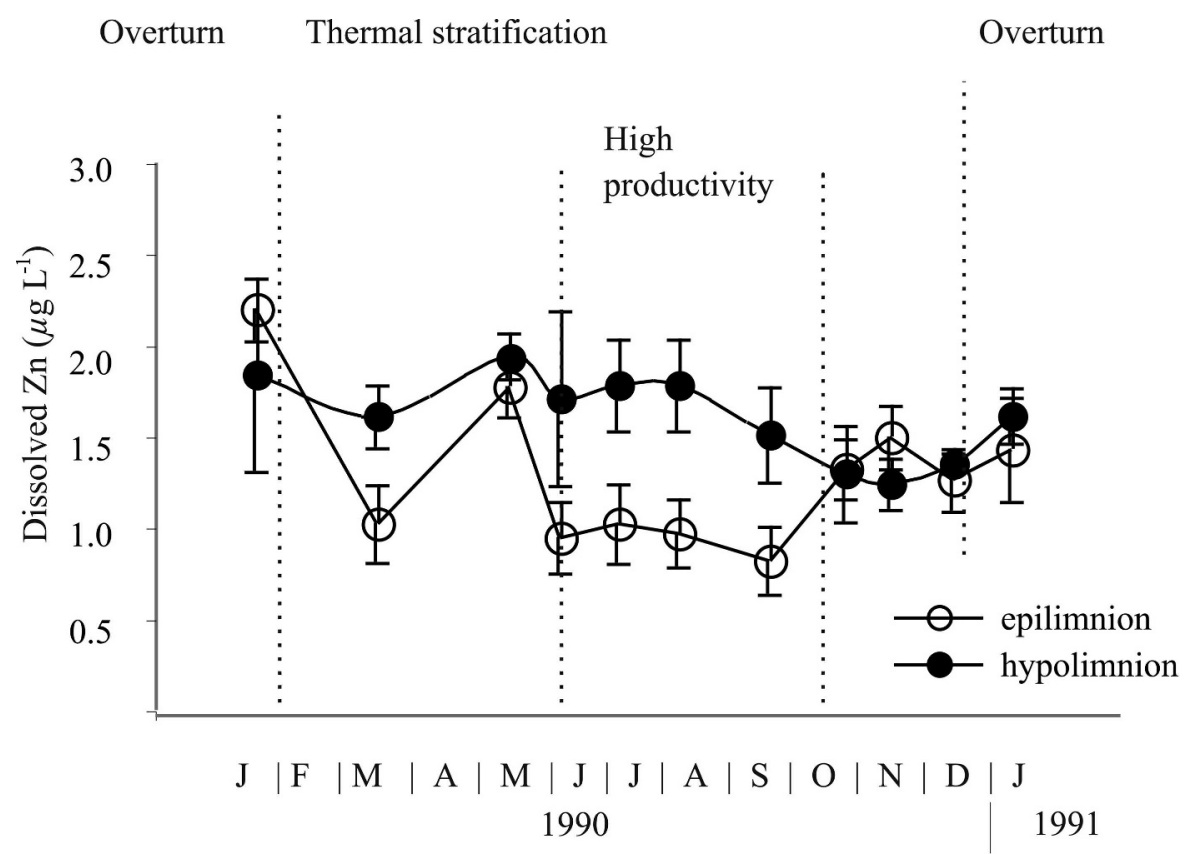

Fig. 2. Average concentration of dissolved $\mathrm{Zn}$ (in $\mu \mathrm{g} \mathrm{L} 1$, samples passed through $0.45 \mu \mathrm{m}$ filters) collected at various depths in the epilimnion (0 to $10 \mathrm{~m})$ and hypolimnion (15 to $31 \mathrm{~m})$ between January 1990 and January 1991. Data taken from Sigg et al. (1996).

In conclusion, our data suggest that seasonal variations in biological uptake, variations in input sources, and adsorption on mineral particles alike influence the $\mathrm{Zn}$ isotope composition of settling particles. This opens up the use of this new isotope system as a tracer of biogeochemical processes in lakes. Figure 4 represents a preliminary attempt to summarize the most important processes leading to isotopic variability in a lake. Further work is warranted to confirm this model in lakes.

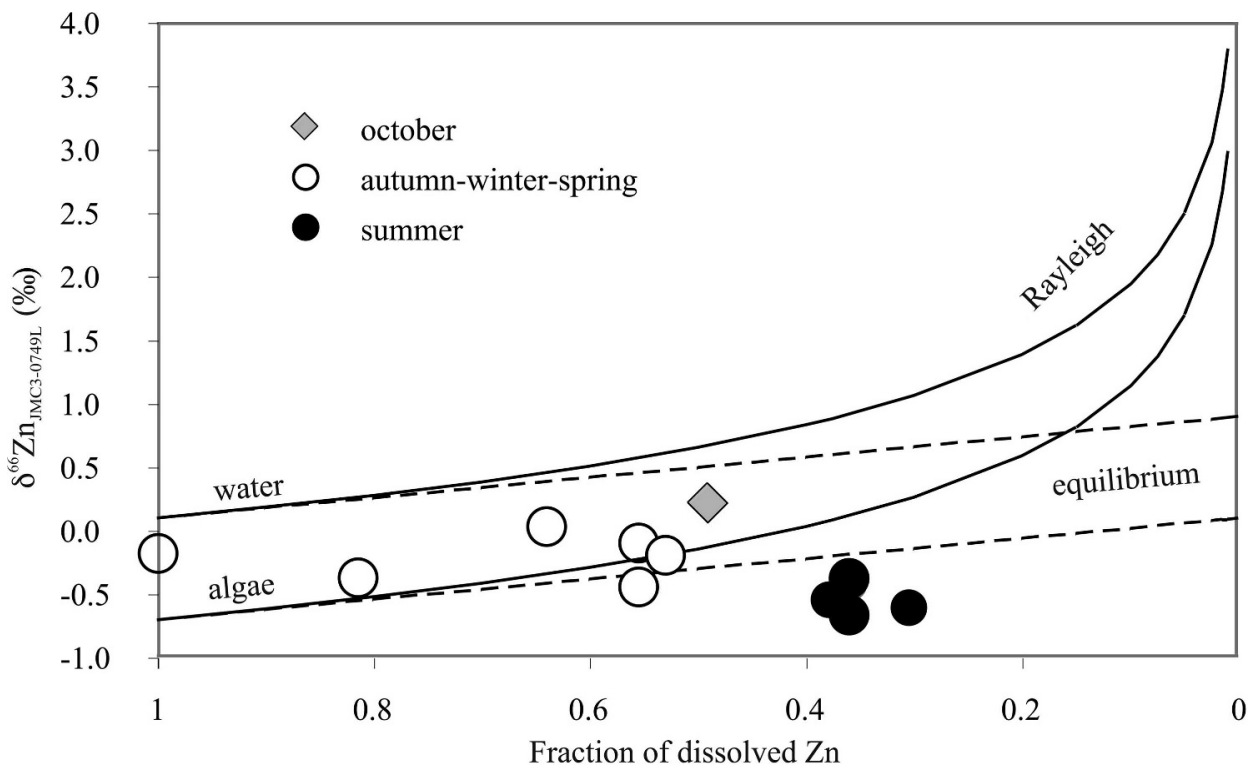

Fig. 3. Rayleigh (solid lines) and equilibrium fractionation (dotted lines) models (see Hoefs [2004] for relevant equations) for the uptake of dissolved $\mathrm{Zn}$ by algae in the epilimnion. The initial $\delta^{66} \mathrm{Zn}$ value is $+0.1 \%$, and the isotopic fractionation factor between algae and solution is $0.8 \%$ (see text for detailed explanations). Also plotted are the measured $\delta^{66} \mathrm{Zn}$ values in the settling particles at $28 \mathrm{~m}$ depth vs. the $\mathrm{Zn}$ remaining in the epilimnion using the data given in Fig. 2 and normalizing against the highest [Zn] measured on 25 January $1990\left(2.20 \mu \mathrm{g} \mathrm{L}{ }^{1}\right)$. 
River input

$\delta^{66} \mathrm{Zn}$ between -0.1 and $0.4 \%$

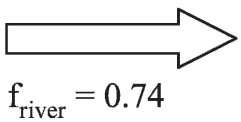

Atmospheric input

$\delta^{66} \mathrm{Zn}$ between -1.0 and $0.5 \%$

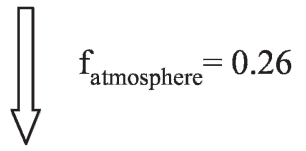

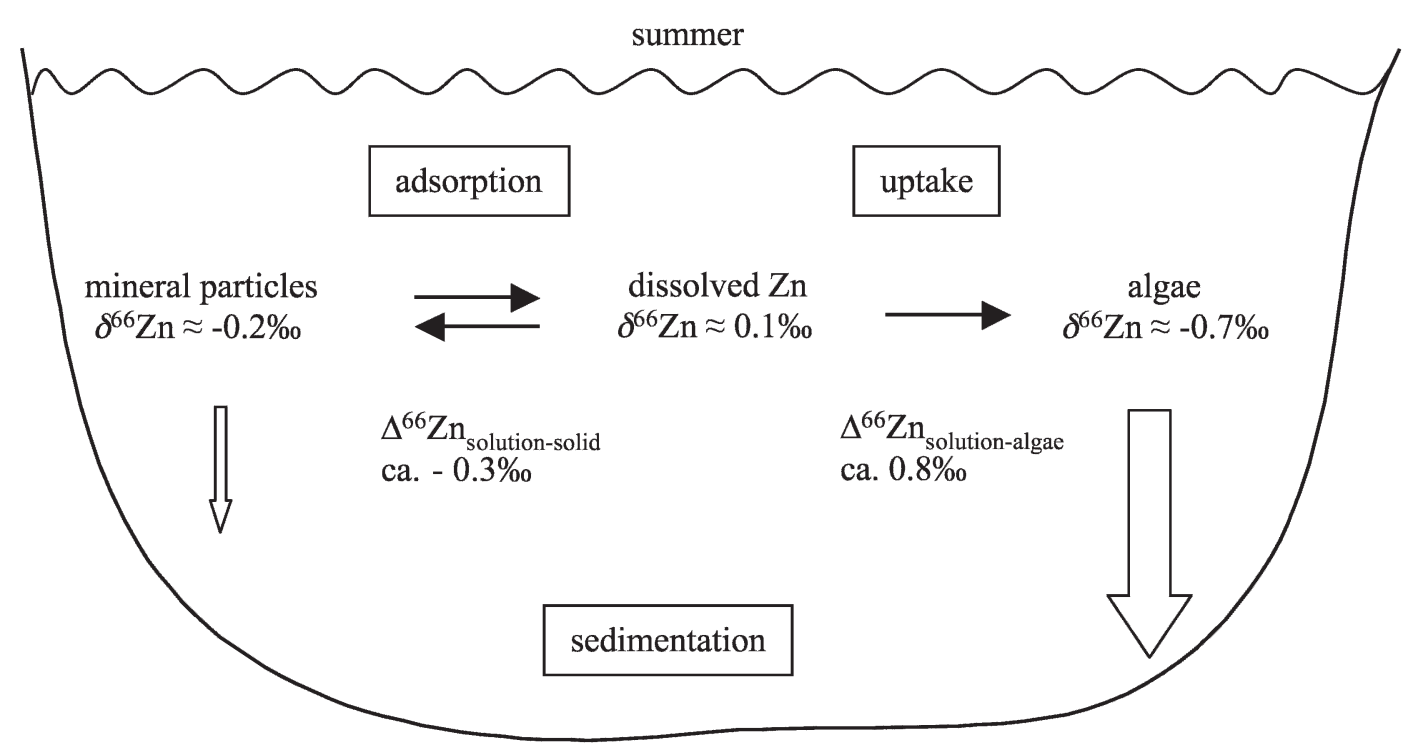

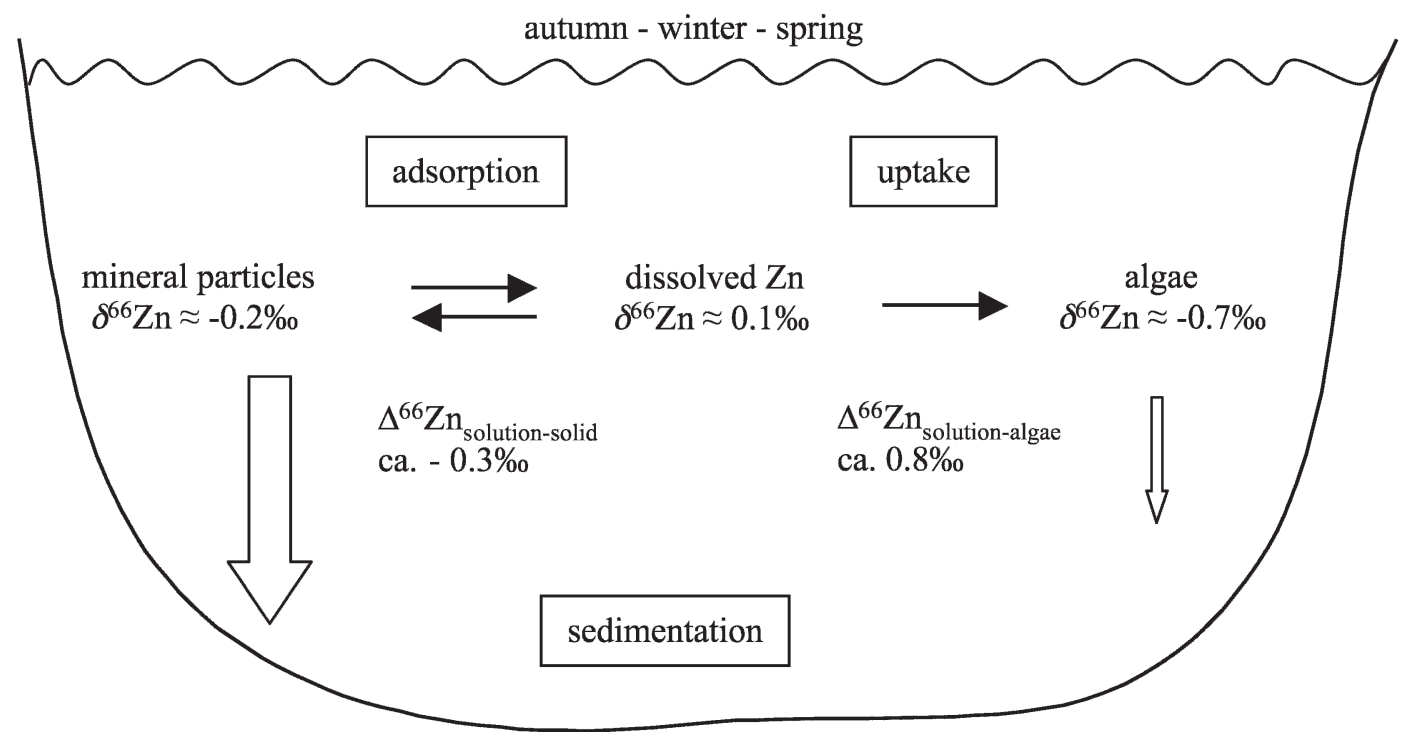

Fig. 4. A preliminary isotope fractionation model for $\mathrm{Zn}$ during its biogeochemical cycle in a lake, showing the cycles during summer (top) and autumn winter spring (bottom). Assuming a separation factor of $+0.3 \%$ between dissolved and particulate $\mathrm{Zn}$ (Borrok et al. 2008), we calculate a $\delta^{66} \mathrm{Zn}$ signature of $+0.1 \%$ for the dissolved $\mathrm{Zn}$ fraction. This value agrees well with the proposed "common anthropogenic Zn signature" (John et al. 2007b; Sonke et al. 2008). The offset between dissolved and sinking particles during the autumn winter spring period is possibly due to the adsorption of dissolved $\mathrm{Zn}$ onto mineral particulates such as manganese, aluminum, or iron oxides (Balistrieri et al. 2008; Juillot et al. 2008). In the summer, algae dominate the composition of the settling particulates. Algae preferentially take up the light $64 \mathrm{Zn}$ isotope with a fractionation factor of $\quad 0.8 \%$ (John et al. 2007a), leading to the $\delta^{66} \mathrm{Zn}$ signature of around $\quad 0.7 \%$ in the settling particles. Adsorption on the algae rich particles seems less important (Knauer et al. 1997). The calculated isotopic signature of dissolved $\mathrm{Zn}$ is in line with the range of previously determined atmospheric and riverine isotopic signatures (see text for references) and lies well on a mixing line between these two end members and their previously determined contributions (26\% from the atmosphere and $74 \%$ from the rivers) to the lake (Sigg et al. 1995, 1996). The estimated values for atmospheric and riverine input are a best guess from the range of isotopic values measured in these sources. There is not a binary switch between sedimentation of mineral particles in the winter and algae in the summer; thus, there is a big arrow to the algae in the summer and a small arrow to the mineral and the reverse in the winter (big arrow to particles and a small arrow to algae). 


\section{Acknowledgments}

We thank Barry Coles for assistance during sample preparation and mass spectrometry. We thank Annette Kuhn and David Kistler for sampling of the settling particles. This work was funded by a Natural Environment Research Council studentship to Kate Peel (NER/S/A/2004/12141). We acknowledge the careful and thoughtful comments of Boaz Luz, Seht G. John, and one anonymous reviewer, which directed us in the right direction. D.J.W. dedicates this paper to Vanessa Garcia Larsen.

\section{References}

Albarède, F. 2004. The stable isotope geochemistry of copper and zinc, p. 409 427. In C. M. Johnson, B. L. Beard and F. Albarède [eds.], Geochemistry of nontraditional stable isotopes: Reviews in mineralogy. Mineralogical Society of America.

Anbar, A. D., and O. Rouxel. 2007. Metal stable isotopes in paleoceanography. Ann. Rev. Earth Planet. Sci. 35: 717746.

Balistrieri, L. S., D. M. Borrok, R. B. Wanty, And I. Ridley. 2008. Fractionation of $\mathrm{Cu}$ and $\mathrm{Zn}$ isotopes during adsorption onto amorphous $\mathrm{Fe}(\mathrm{III})$ oxyhydroxide: Experimental mixing of acid rock drainage and ambient river water Geochim. Cosmochim. Acta 72: 311328.

Bermin, J., D. Vance, C. Archer, and P. J. Statham. 2006. The determination of the isotopic composition of $\mathrm{Cu}$ and $\mathrm{Zn}$ in seawater. Chem. Geol. 226: 280297.

Borrok, D. M., D. A. Nimick, R. B. Wanty, and W. I. Ridley. 2008. Isotopic variation of dissolved copper and zinc in stream waters affected by historical mining Geochim. Cosmochim. Acta 72: 329344.

Bruland, K. W. 1980. Oceanographic distribution of cadmium, zinc, nickel and copper in the North Pacific. Earth Planet. Sci. Lett. 47: 176198.

Chapman, J., T. F. D. Mason, D. J. Weiss, B. J. Coles, and J. J. WiLKINSON. 2006. Chemical separation and isotopic variations of $\mathrm{Cu}$ and $\mathrm{Zn}$ from five geological reference material. Geostand. Geoanal. Res. 30: 516.

Chen, J., J. Gaillardet, and P. Louvat. 2008. Zinc isotopes in the Seine River waters, France: A probe of anthropogenic contamination. Environ. Sci. Technol. 42: 64946501.

Cloquet, C., J. Carignan, M. F. Lehmann, and F. Vanhaecke. 2007. Variations in the isotopic composition of zinc in the natural environment and the use of zinc isotopes in biogeosciences: A review. Anal. Bioanal. Chem. 390: 451463.

, J. Carignan, And G. Libourel. 2006. Isotopic composi tion of $\mathrm{Zn}$ and $\mathrm{Pb}$ atmospheric depositions in an urban/peri urban area of northeastern France. Environ. Sci. Technol. 40: 65526600

Frausto Da silva, J. J. R., and R. J. P. Williams. 2000. The biological chemistry of the elements. Oxford Univ. Press.

Gélabert, A., O. S. Pokrovsky, J. Viers, J. Schott, A. Boudou, ANd A. Feurtet Mazel. 2006. Interaction between zinc and freshwater and marine diatom species: Surface complexation and $\mathrm{Zn}$ isotope fractionation. Geochim. Cosmochim. Acta 70: 839857.

Gioia, S., D. J. Weiss, B. J. Coles, T. Arnold, and M. Babinski. 2008. Accurate and precise measurements of $\mathrm{Zn}$ isotopes in aerosols. Anal. Chem. 80: 97769780.

Hoefs, J. 2004. Stable isotope geochemistry. Springer.

John, S. G., R. W. Geis, M. A. Saito, and E. A. Boyle. $2007 a$. Zinc isotope fractionation during high affinity and low affinity zinc transport by the marine diatom Thalassiosira oceanica. Limnol. Oceanogr. 53: 27102714.

, J. G. Park, Z. T. Zhan, and E. A. Boyle. 2007b. The isotopic composition of some common forms of anthropo genic zinc. Chem. Geol. 245: 6169.
Juillot, F., C. Marechal, M. Ponthieu, S. Cacaly, G. Morin, M. Benedetti, J. L. Hazemann, O. Proux, and F. Guyot. 2008. $\mathrm{Zn}$ isotopic fractionation caused by sorption on goethite and 2 lines ferrihydrite. Geochim. Cosmochim. Acta 72: 48864900.

Knauer, K., R. Behra, and L. Sigg. 1997. Effects of free $\mathrm{Cu}^{2+}$ and $\mathrm{Zn}^{2+}$ ions on growth and metal accumulation in freshwater algae. Environ. Toxicol. Chem. 16: 220229.

Maréchal, C. N., E. Nicolas, C. Douchet, and F. Albarède. 2000. Abundance of zinc isotopes as a marine biogeochemical tracer. Geochem. Geophys. Geosys. 1: 1015, doi: 10.1029/ 1999GC000029.

Mason, T. F. D., D. J. Weiss, M. Horstwood, R. R. Parrish, S. S. Russell, E. Mullane, and B. J. Coles. 2004. High precision $\mathrm{Cu}$ and $\mathrm{Zn}$ isotope analysis by plasma source mass spectrometry: Part 2: Correcting for mass bias discrimination effects. J. Anal. At. Spectrom. 19: 218226.

Mattielli, N., M. Yao N'Guessan, J. Rimetz, J. Petit, D. Weis, K. Deboudt, and F. Flament. 2005. Isotopic study of two biolimiting metals $(\mathrm{Zn}$ and $\mathrm{Cu})$ in industrial aerosols. Geophys. Res. Abstr. 7: 10030.

Peel, K., D. J. Weiss, J. Chapman, T. Arnold, and B. J. Coles. 2007. A simple combined sample standard bracketing and inter element correction procedure for accurate and precise $\mathrm{Zn}$ and $\mathrm{Cu}$ isotope ratio measurements. J. Anal. At. Spectrom. 22: 18 .

Pichat, S., C. Douchet, and F. Albarède. 2003. Zinc isotope variations in deep sea carbonates from the eastern equatorial Pacific over the last 175ka. Earth Planet. Sci. Let. 210: 167178.

Pokrovsky, O. S., J. Viers, and R. Freydier. 2005. Zinc stable isotope fractionation during its adsorption on oxides and hydroxides. J. Colloid Interface Sci. 291: 192200.

Reynolds, G. L., and J. Hamilton Taylor. 1992. The role of planktonic algae in the cycling of $\mathrm{Zn}$ and $\mathrm{Cu}$ in a productive soft water lake. Limnol. Oceanogr. 37: 17591769.

SANTSCHI, P. H. 1984. Particle flux and trace metal residence time in natural waters. Limnol. Oceanogr. 29: 11001108.

SigG, L., D. Kistler, And M. M. Ulrich. 1996. Seasonal variations of $\mathrm{Zn}$ in a eutrophic lake. Aquat. Geochem. 1: 313328.

, A. Kuhn, H. Xue, E. Kiefer, and D. Kistler. 1995. Cycles of trace elements (copper and zinc) in an eutrophic lake, p. 177 194. In C. R. O’Melia, C. P. Huang and J. J. Morgan [eds.], Aquatic chemistry: Interfacial and interspecies processes. Adv. Chem. Ser. American Chemical Society.

Sivry, Y., J. Riotte, J. E. Sonke, S. Audry, J. Schafer, J. Viers, G. Blanc, R. Freydier, and B. Dupré. 2008. Zn isotopes as tracers of anthropogenic pollution from $\mathrm{Zn}$ ore smelters: The Riou Mort Lot river system. Chem. Geol. 255: 295304.

Sonke, J. E., Y. Sivry, J. Viers, R. Freydier, L. Dejonghe, L. André, J. K. Aggarwal, F. Fontan, and B. Dupré. 2008. Historical variations in the isotopic composition of atmo spheric zinc deposition from a zinc smelter. Chem. Geol. 252: 145157.

Thompson, M., AND J. Walsh. 1989. Handbook of inductively coupled plasma spectrometry. Blackie \& Son.

Viers, J., P. Oliva, A. Nonell, A. Gélabert, J. E. Sonke, R. Freydier, R. Gainville, And B. Dupré. 2007. Evidence of Zn isotopic fractionation in a soil plant system of a pristine tropical watershed (Nsimi, Cameroon). Chem. Geol. 239: 124137.

Wehrli, B., G. Friedl, and A. Manceau. 1995. Reaction rates and products of manganese oxidation at the sediment water interface, p. 111 134. In C. P. Huang and J. J. Morgan [eds.], Aquatic chemistry: Interfacial and interspecies processes. Adv. Chem. Ser. American Chemical Society. 
Weiss, D., T. F. D. Mason, N. Rausch, T. Arnold, B. J. Coles, T. M. Nieminen, L. UkonmaAnaho, and J. J. Wilkinson. 2007. Atmospheric deposition and isotope biogeochemistry of zinc in ombrotrophic peat. Geochim. Cosmochim. Acta 71: 34983517.

Wilkinson, J. J., D. J. Weiss, B. J. Coles, and T. F. D. Mason. 2005. Zinc isotope variation in hydrothermal systems: Preliminary evidence from the Irish Midlands orefield. Econ. Geol. 100: 583590.

Xue, H., D. Kistler, And L. Sigg. 1995. Competition of copper and zinc for strong ligands in a eutrophic lake. Limnol. Oceanogr. 40: 11421152.
, AND L. SigG. 1994. Zinc speciation in lake waters and its determination by ligand exchange with EDTA and different pulse anodic stripping voltammetry. Anal. Chim. Acta 284: 505515.

Associate editor: Mary I. Scranton

Received: 06 November 2008 Accepted: 17 April 2009 Amended: 15 May 2009 